\title{
The growth of 'botos feeding tourism', a new tourism industry based on the boto (Amazon river dolphin) Inia geoffrensis in the Amazonas State, Brazil
}

Luiz Cláudio Pinto de Sá Alves ${ }^{1,2^{*}}$, Artur Andriolo ${ }^{1,2,3}$, Mark Bryan Orams ${ }^{4} \&$ Alexandre de Freitas Azevedo ${ }^{5}$

${ }^{1}$ Instituto Aqualie, Rua Edgard Werneck, 428/32, 22763-010, Rio de Janeiro, RJ, Brazil.

${ }^{2}$ Programa de Pós-graduação em Meio Ambiente, Universidade do Estado do Rio de Janeiro, Rua São Francisco Xavier, 524/12005-F, Maracanã, 20550-900, Rio de Janeiro, RJ, Brazil.

${ }^{3}$ Departamento de Zoologia, Instituto de Ciências Biológicas, Universidade Federal de Juiz de Fora, Campus Universitário, 36036-330, Juiz de Fora, Minas Gerais, Brazil.

${ }^{4}$ New Zealand Tourism Research Institute, School of Hospitality and Tourism, AUT University, Private Bag 92006, Auckland 1010, Aotearoa, New Zealand.

${ }^{5}$ Laboratório de Mamíferos Aquáticos e Bioindicadores, Faculdade de Oceanografia, Universidade do Estado do Rio de Janeiro, Rua São Francisco Xavier, 524/4002-E, Maracanã, 20550-013, Rio de Janeiro, RJ, Brazil.

\begin{abstract}
The Amazon's reputation and ability to draw tourists is strongly associated with the natural environment and with tourist's ability to sight and interact with iconic animals. In Brazil, four cases of aggregations of wild boto (Amazon River dolphin; Inia geoffrensis), becoming conditioned to human contact through food provisioning are occurring in Amazonas State, Central Amazon, where tourists can feed, touch and swim with the botos. The feeding of wild dolphins imposes significant risks, both for the dolphins and for the tourists, and these dangers are evident at Novo Airão City, which is the longest established of the four mentioned cases. There are few rules imposed, inadequate infrastructure and no specialized employee training or surveillance. Competitive, aggressive interactions between dolphins, pushing, ramming and biting are common and a number of dangerous interactions between the dolphins and tourists have been observed. It is evident that the establishment of this tourist-dolphin interaction is facilitated by the deliberate feeding of the dolphins and that this activity has become financially lucrative for local people. Despite bringing benefits to the region, the growth of this 'botos feeding tourism' activity in the Amazon is currently poorly managed and there is a high risk of injury or fatality if interactions continue to develop without improved and careful management.
\end{abstract}

Additional key words: swim-with-dolphins, Amazon, wildlife management.

Resumo (O crescimento do "turismo de alimentação de botos", uma nova indústria de turismo baseada no boto da Amazônia, Inia geoffrensis, no Estado do Amazonas, Brasil) - Na Amazônia, a habilidade e tradição de atrair turistas estão fortemente associadas ao ambiente natural e à oferta turística de observação e interação com animais icônicos. No Brasil, quatro casos de agregações de botos da Amazônia (também chamado de boto-vermelho ou boto-cor-de-rosa; Inia geoffrensis) condicionados ao contato humano através da alimentação deliberada vêm ocorrendo no Estado do Amazonas, na Amazônia Central, onde os turistas podem alimentar, tocar e nadar com os botos. A alimentação de golfinhos selvagens implica significantes riscos, tanto para os animais como para os turistas, e esses riscos são evidentes na cidade de Novo Airão, que é o mais antigo dos quatro casos mencionados. Existe pouca regulamentação, infraestrutura inadequada e ausência de profissionais especializados para monitorar as atividades. Interações competitivas e agressivas, empurrões, investidas e mordidas são comuns entre os botos, assim como interações de risco entre os turistas e os animais. É evidente que o estabelecimento dessa interação homem-golfinho é facilitado pela alimentação deliberada e que a atividade se tornou financeiramente lucrativa para a população local. É também claro que essa é uma atividade repleta de riscos, tanto para os botos como para os turistas. Apesar de trazer benefícios para a região, o crescimento desse 'turismo de alimentação de botos' na Amazônia é atualmente mal manejado e existe o risco de acidentes com ferimentos ou mesmo fatalidades se a atividade continuar a ser desenvolvida dessa forma.

Palavras-chave adicionais: nado com golfinhos, Amazônia, manejo da vida silvestre.

There are a number of accounts throughout the world of wild individual dolphins that frequent a particular location and become habituated to human presence (Orams 1997). This habituation can lead to regular interactions with humans through playing, touching, feeding and

\footnotetext{
*Corresponding author: 1cpsalves@yahoo.com.br

Communicator editor: Flora Acuña Junca

Recebido: 26 jan. 2010; aceito: 16 maio 2010.
}

communicating (Orams 1994). While there are a number of hypotheses, it is still not clear why these dolphins seek human company (Lockyer 1990). In Brazil, Santos (1997) described a case of a lone sociable bottlenose dolphin, Tursiops truncatus (Montagu, 1821), that eventually injured about 30 tourists, one of them fatally. Despite the wide range of reports of sociable wild individual dolphins, there are few reported cases involving groups of dolphins. Notable

Sitientibus série Ciências Biológicas 11(1): 8-15. 2011. 
exceptions are the significant long-term relationships between a group of dolphins and humans that occur at Monkey Mia, Shark Bay in Western Australia (Connor \& Smolker 1985) and at Tangalooma on the western shores of Moreton Island, offshore from the city of Brisbane, also in Australia (Orams 1994). Both of these interactions are promoted as tourism attractions and are facilitated by deliberate provisioning (feeding) of these groups of dolphins (Tursiops sp.).

Both provisioning and swim-with-dolphins activities which are promoted as a commercial tourism activity have increased over the past decade (Hoyt 2001). Human provisioning of wild dolphins as a tourism attraction has become controversial (Orams 2002) but continues to occur at many locations. Given the predicted continued growth of coastal, marine and nature based tourism, it seems highly likely that there will be an increase in the tourist demand for opportunities to see and interact with marine wildlife in natural settings (Orams 1994), and also with freshwater species. In Brazil, four previously unreported cases of aggregations of wild boto (Amazon River dolphin), Inia geoffrensis (de Blainville, 1817), becoming conditioned to human contact are occurring in Amazonas State (Figure 1), Central Amazon. From May to August 2008 and from March to May 2009, an Ad libitum sampling method (Altmann 1974) was used to record aspects of the botos' behavior related to the provisioning and other interactions between botos and people in the four locations where interactions occur. Given the risks associated with human wild-dolphin interactions (Orams 2002), it is important to document, understand and carefully manage them.

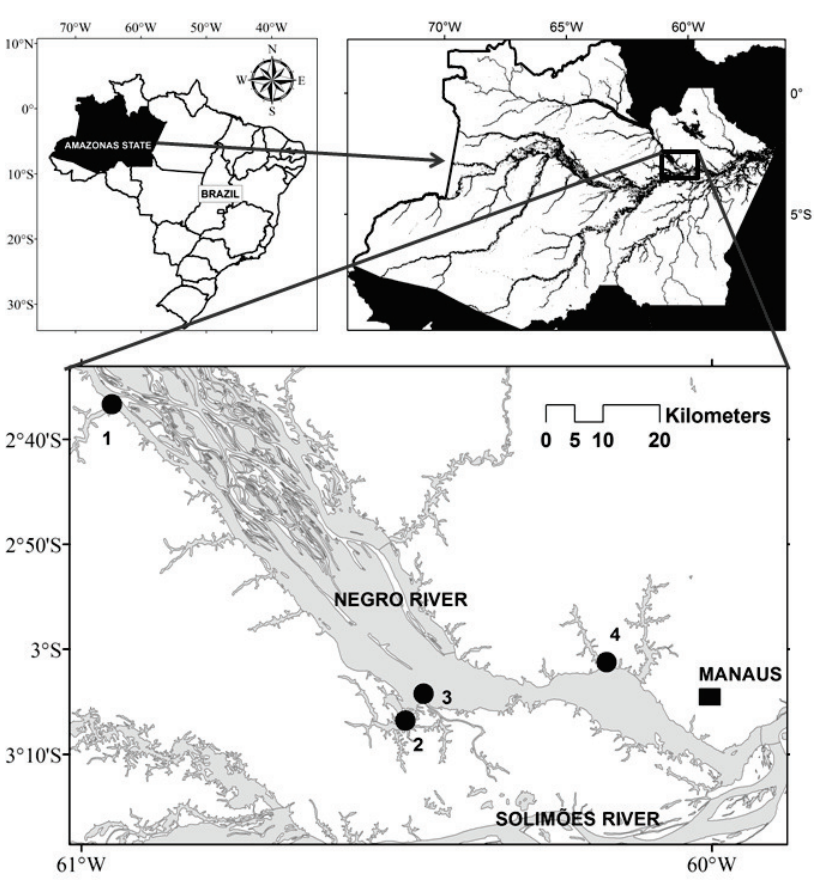

Figure 1. Sites of "botos feeding tourism" reported in this study: 1- Novo Airão, 2- Acajatuba River, 3- Ariaú and 4- Tarumã-Mirim River, State of Amazonas, Brazil.

\section{“Botos Feeding TourisM” in Novo Airão}

At Novo Airão, a small town on the southern banks of the Negro River, $115 \mathrm{~km}$ northwest of the city of Manaus (the Amazonas State Capital), locals have regularly provisioned boto since 1998 from a small floating wooden structure located inside a national park area (Figure 2).

Accordingly to Brazilian law number 9985, a national park has as its basic objective the preservation of natural ecosystems and areas of great ecological importance and scenic beauty. National parks allow scientific research, the development of environmental education and interpretation, and appropriate recreational activities related to nature and eco-tourism (Brasil 2000).

The activity of provisioning boto has grown to become an important tourism ('botos feeding tourism') attraction in Novo Airão and probably the most significant economic activity for the small town and its inhabitants. Thus, this tourism activity has been the catalyst for economic development and many claim it has helped lift the town from poverty. However, others (e.g., Romagnoli 2009) argue that the economic benefits derived from the activity do not flow to the great majority of the inhabitants of the city and, as a consequence, the benefits are shared by few.

Provisioning, swimming and other interactions (especially touching and observing) with boto has become the main attraction and also the most profitable activity for the floating structure managers, and has become the main and most profitable attraction, so much so that meals are not served anymore. Alcohol sales (mainly beer) are the other major income, and is often linked to the boto tourism activities, especially during weekends when customers spend hours swimming with the botos and drinking beer.

The feeding of wild dolphins imposes significant risks, both for the dolphins and for the tourists and these dangers are evident at Novo Airão. This activity is not regulated in Brazil. Moreover, there is inadequate infrastructure supporting this interaction nor specialized employee training or surveillance of the activity to minimize risks. As foreign English speaking tourists are a large proportion of the total number of tourists participating in the activities and employees do not speak English, the rare attempts to control bad behavior may be constrained by communication difficulties.

The floating structure itself has very few controls on boto tourism activities. The few existing rules are posters fixed on the floating structure walls. These rules are: 1- do not jump from the platforms into the water, 2- do not tease the dolphins, and 3- the schedule to feed the botos goes from 9:00 to 12:00 and from 15:30 to 17:30 from Monday to Saturday and on Sundays from 9:00 to 12:00. None of these rules are adhered to and there is no accepted code of conduct for the tourists to follow while interacting with the animals. There are no life-jackets provided and no maximum number of swimmers allowed in the water. Several tourists have 

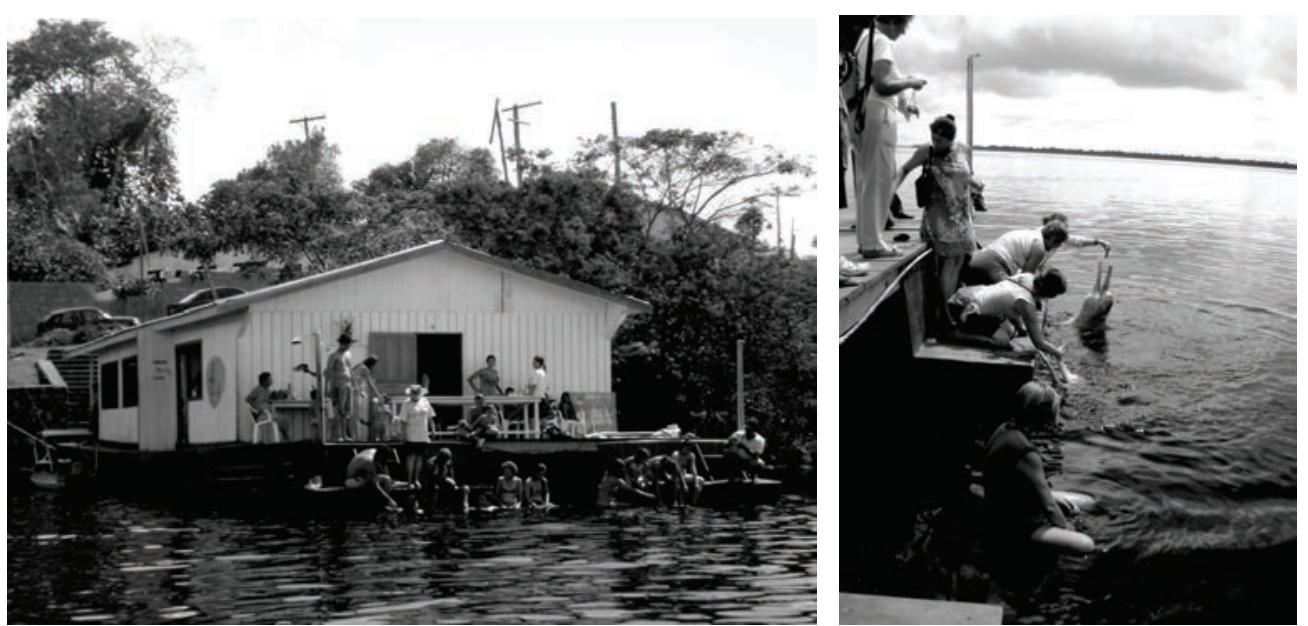

Figure 2. Floating wooden structure where interactions occur in Novo Airão, State of Amazonas, Brazil (May 2008).

been accidentally bitten while feeding the botos (Figure 3), and there have been numerous other dangerous incidents. Several cases of potentially harmful human behaviors have also been observed (for example, attempting to restrain or ride the dolphins, striking the dolphins and feeding inappropriate objects).

The dolphins are today totally conditioned to the close proximity and physical contact with tourists through food offer. The numbers of animals being provisioned has escalated to involve at least 13 regularly fed individuals in 2009. The gender balance may also influence the risk of potentially aggressive behaviour. Previous genetic research on boto in this area (Gravena 2007) has confirmed that at least 10 of the provisioned individuals are males. Accordingly to Martin \& da Silva (2006), adult male botos are generally much more heavily scarred than adult females, and the most plausible explanation for the difference between the sexes is that much of the scarring on adult males is caused by intermale aggression. In their study of 'pushy' behavior (defined as forceful contact between a dolphin's rostrum and a person in the water) in a bottlenose

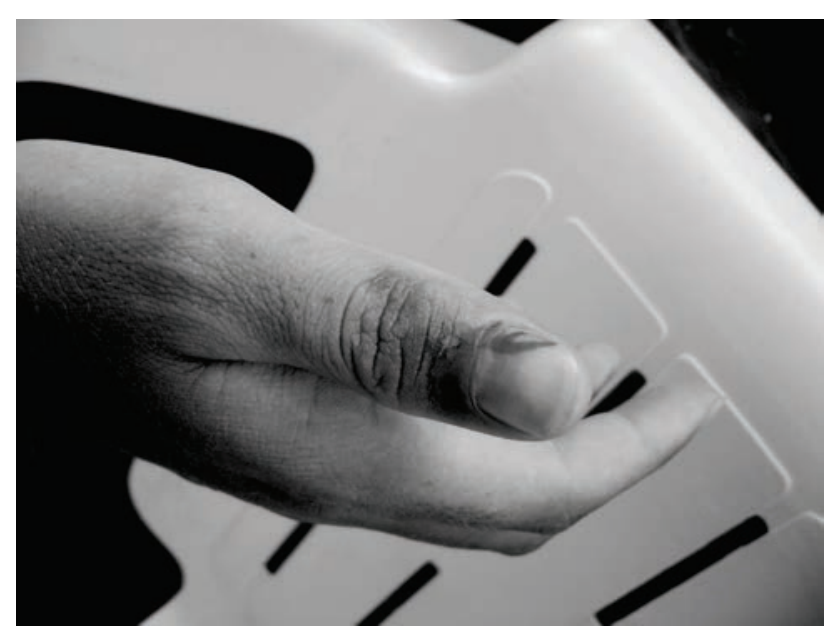

Figure 3. Consequences resulting from accidental bites at Novo Airão, State of Amazonas, Brazil (June 2008). dolphin feeding program at Tangalooma, Australia, Orams et al. (1996) stated that when the adult males were not present, the feeding sessions were less likely to be pushy. Many dolphinariums (captive dolphin facilities) exclude male dolphins from interaction programs and shows, due to their tendency to be more aggressive than females (Shane et al. 1986). The fact that most, if not all of the individuals participating in the interactions in this location are males adds concerns to this particular case.

The fish provided to the dolphins are not hygienically handled before being sold to the tourists. Fish are frequently left on the floor and stepped on before being given to the boto (Figure 4). The fish are put inside plastic bags to be sold to the tourists, which frequently use them as bait to attract the botos closer, putting in danger the animals that sometimes grab the bags and are at risk to ingest them. The fish are generally sold still frozen. Some people put the fish on the water for some seconds, before giving them to the animals, but in most situations fish still frozen are given to the boto. There is no system of measuring or controlling the quantity of fish given to individual boto.

The floating structure is located inside a small bay during high water season (water level vary $12 \mathrm{~m}$ in average throughout the year). This bay forms a harbor for Novo Airão and provides an anchorage for many boats. Many residential houses, handicraft stores and bars are adjacent to the harbor and bars are responsible for considerable noise and water pollution. The harbor is subject to significant boat traffic and, due to poor water circulation, is polluted with sewage, oil and other human created discharges. Visitors and locals frequently throw plastic bags and other waste into the water, however, some tourism guides and tourists work to take some garbage out of the water. A particular problem is caused by locals waiting to board local ferries and transport vessels who commonly throw many waste items into the water in the harbor.

In 2009, a new harbor was built, only a few meters from the interaction activities, creating many political

Sitientibus série Ciências Biológicas 11(1): 8-15. 2011. 


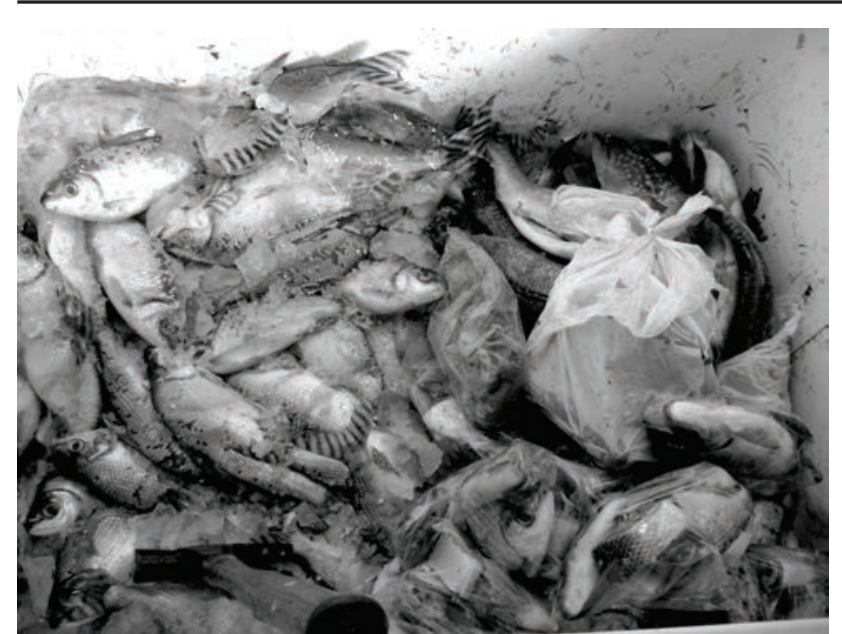

Figure 4. Frozen fish used to feed the botos; fish bags ready to be sold are down on the right (Novo Airão, State of Amazonas, Brazil; April 2008).

discussions in the town, but the floating structure has remained and, as a consequence of increased vessel traffic, risks of boat-strike for both the dolphins and humans have increased, besides increases in noise and water pollution. During low water season, the floating structure is re-located a few hundred meters from this harbor further toward the main Negro River flow. As a consequence, there is greater water movement and pollutants are carried downstream more easily.

Interactions between local residents (or visitors from nearby cities) and boto also occur away from the floating structure. These incidents take place on the river beach, very close to the floating structure. Tourists attract the dolphins by splashing the water with hands and offering fish. On these occasions, the tourist-dolphin interactions are also not controlled or supervised. As a consequence, incidents resulting in injury to people are frequently observed. In particular, many people were observed to be bitten by dolphins while feeding them and on one occasion an individual retaliated by punching the dolphin with a closed fist. Local people informed researchers of a case where a person feeding and harassing the dolphins was rammed in the chest by a dolphin (dolphin's rostrum driven into the man's chest area) in 2008 and, as a consequence this person was taken to a hospital in Manaus for treatment.

Cruise ship activities. On Tuesday mornings each week, interaction activities at the floating structure are reserved for the patrons of a cruise ship. They have a fixed package for the whole morning, and tourists do not have to pay individually to feed the dolphins, since this activity is already included in their tourism package. Other tourists are denied entrance to the floating structure during this time. Tourists are divided into groups of 25 or less and ferried to the floating structure on small outboard motor powered boats. Up to five groups of tourists from the ship visit the floating structure and feed the dolphins each Tuesday morning. Generally they are given a brief lecture inside the floating structure, which is given in Portuguese by a member of the structure's staff and simultaneously translated into English or another language by their guide (each group has one guide), if needed. After the lecture, the group is directed to the rear of the floating structure, in order to feed the dolphins. During all interaction sessions (generally less than $20 \mathrm{~min}$ in duration), tourists are supervised by their guide. The guide gives instructions regarding how to behave and feed the dolphins (sometimes they also give information about the case of botos provisioning and botos biology and behavior; in this case, most of the time, incorrect information). Instructions include the necessity to push the jumping animals away from the wooden border of the feeding platform with one hand while giving fish with the other. Each tourist receives only two or three pieces of fish, and generally only two people feed the dolphins at the same time. Some tourists are allowed to enter the water with the animals, but always under supervision of the guide. These simple practices apparently reduce the incidence of high risk situations.

School visits. Some education regarding boto has been undertaken in the Novo Airão area and these activities may also be responsible for changing attitudes of locals towards the dolphins. For example, on 21 May 2008, 84 children from two local schools (6-13 years of age) participated in an interaction session with botos. Three teachers were together with the group. The children were given a talk by the owner of the floating structure and showed intense interest in the dolphins. Many children expressed fear about the boto; much of this fear appeared related to local myths. Questions such as: "are the boto evil animals?", "do the boto will take us to the bottom of the river?" are derived from local mythology and superstitions regarding boto. After the lesson, children were divided into four groups of 21 children and taken to feed and interact with the animals. Some instructions were given to the students about how to offer fish to the dolphins. Initially the children stayed distant, but after a short period, they started feeding and touching the botos. This experience resulted in expression of great happiness. Interviews were conducted with some of the children and with the teachers after the session. These interviews revealed the significance of the experience with regard to participant's attitudes and views toward the boto. One local teacher, when asked about the positive points of this activity, said: "It creates conscience that the superstitions are lies". One eight year old child commented: "I want the boto to live forever, and don't want my father to kill them!". This shows a great potential of this activity to increase awareness and perception of boto by the population, acting in favor of the conservation of this animal and its natural environment. Unfortunately, this potential has been wasted. Romagnoli (2009) stated that "sensitization" of the locals is not expressive, and few know about the species, showing no involvement with the activity conducted at the floating structure. 


\section{“Botos Feeding Tourism” IN ARIAÚ}

A second program where boto are being provisioned as a tourism attraction occurs at a commercial tourism facility also based on a floating structure (Alves et al. 2009) and located in another conservation unit area, in the city of Iranduba. It is located near the Negro River, in a small tributary named Ariaú, and is approximately 20 min away from the Ariaú Amazon Towers Hotel accommodation and main facilities. At this location water from both the Negro and Solimões Rivers converges, resulting in an abundance of fish.

The development of this interaction with the boto differs in many aspects from the Novo Airão case. Its beginning was not opportunistic as in Novo Airão; rather, it was a deliberate attempt to create an opportunity for tourists to interact with boto after observing the popularity of the Novo Airão case. Many boto already frequented the area before the beginning of habituation attempts. The development of this provisioning as a tourism attraction bears a close resemblance to that described by Orams (1994) at Tangalooma, Australia. Today, according to Ariaú's staff, more than 25 individually identifiable dolphins are known to frequent the area and accept fish hand-outs from staff and resort guests.

At this second interactions site, environment differs greatly from that at Novo Airão. Because it is located in a remote setting, there is little boat traffic and no nearby residences or human activity. As a consequence, the river where the boto interact with people is relatively clean and they are less disturbed by human activity. Furthermore, because the interaction is specifically created as an attraction for resort guests, the provisioning is more carefully managed. For example, all tourists wishing to feed and interact with the boto are supervised by a staff member, those tourists who swim with the dolphins are sometimes required to wear a life-jacket (buoyancy aid) and the feeding of fish is better monitored. An interesting feature at the Ariaú is a submersed platform where tourists can enter the water and stand on the platform to feed the dolphins. Despite that, risks are evident as in the previously mentioned case.

The activity has proved popular with tourists visiting the resort and staff report that the numbers of people participating in the provisioning facilitated interactions are increasing and, frequently, over 100 tourists participate in one day; these tourists are charged high prices to participate and, as a consequence, the development of this provisioning has proved financially lucrative.

Bototherapy. An initiative to establish an interaction with boto as a tool for therapeutic sessions with disabled children occurs since 2008, at this second site. DolphinAssisted Therapy (DAT) is an increasingly popular choice of treatment for illness, disability and psychopathology in children and adults (Whale and Dolphin Conservation

Sitientibus série Ciências Biológicas 11(1): 8-15. 2011.
Society 2006). DAT formally began in the 1970s and has grown over the years into a highly lucrative business with facilities at a variety of locations around the world (Marino $\&$ Lilienfeld 2007). According to these authors, the claims made by DAT operators have been subject to little or no scientific scrutiny; moreover, there has been no significant increase in the rate of peer-reviewed papers on DAT from the 1970s to the present. Yet DAT programs continue to proliferate and new programs are appearing in a range of new locations. As a consequence, it is argued that DAT's popularity greatly outstrips its meager research base and is potentially exploitive of both dolphins and the tourists who pay for these experiences (Marino \& Lilienfeld 2007).

This second interactions site is a further example of DAT's expansion to a new location and with a different species. It started in Novo Airão in 2005, and was transferred to Ariaú in 2008. It started as an experimental activity. Around once per month at Ariaú, a small group of children with physical or psychological disabilities and/or emotional problems coming from a local orphanage participated in these DAT sessions. Today treatment is available to the hotel's guests, at very high prices.

Competition amongst botos. Over time, competition amongst the provisioned botos for access to the fish at both locations has resulted in increased aggression, both between dolphins and toward the tourists. Boto pushing and shoving, leaping and biting both one another and tourists are now commonplace. This kind of escalation of dolphin's behavior from habituation to increased confidence, assertiveness, 'pushiness' and potential eventual aggression was observed at Tangalooma and reported by Orams et al. (1996). The risk of such behavior is widely understood in the case of provisioned wildlife (Orams 2002) and is exemplified by the cases described here. The potential consequences of such an escalation were dramatically illustrated in the case of Tião, a solitary sociable bottlenose dolphin, in São Paulo State, in 1994. Santos (1997) reported that bathers' attempting to interact with the dolphin behavior varied from simply touching the animal to grabbing its fins, hitting it and jumping on it; some bathers even attempted to put ice-cream sticks into its blowhole. The author stated that the dolphin reacted aggressively when repeatedly harassed and eventually injured 29 bathers, who were sent to the hospital with minor injuries. On 8 December 1994, Tião struck a 30-years-old bather who died several hours later from internal bleeding due to a stomach rupture.

\section{“Botos Feeding Tourism" in Acajatuba AND TARUMÃ-Mirim RIVERS}

A third and a fourth site where interactions occur are located at the Acajatuba River (Iranduba City) and at the Tarumã-Mirim River (Manaus City; both also located inside conservation units areas). Both rivers are tributaries of the 
Negro River. Acajuba started its activity in 2006 whereas Tarumã-Mirim started at the beginning of 2009; tourists are also charged to feed the botos in both places. The two projects were deliberate attempts to create opportunities for tourists to interact with boto after observing the popularity of previous cases. In both cases, they have submersed platforms for tourists to interact with the dolphins and they are located in less human disturbed surroundings than Novo Airão, but they also did not implement strict regulations for the activity, as observed for the previous cases. These activities are now the main income of the owners of those floating structures and their families (very similar to the one in Novo Airão).

\section{BraZilian Legislation}

One of the objectives of the Brazilian law number 11771 (the Tourism Law; Brasil 2008a) is to promote, decentralize and regionalize the tourism activity, stimulating sustainable and safe tourist activities, with local involvement and the effective participation of the recipient communities in the generated benefits. It also states as its objectives the propitiation of sustainable tourism in natural areas, promoting the activity as a vehicle of environmental education and interpretation and incentivizing the adoption of conducts and practices of minimum impact compatible with the conservation of the natural environment.

Brazilian legislation pertaining to tourism involving animals is limited, particularly concerning aquatic mammals. A formal tourist operation to offer the experience of swimwith-humpback whales, Megaptera novaeangliae (Borowski, 1781), was identified to occur in Brazil in 2003. Nevertheless, swimming with whales is illegal in Brazil (Rose et al. 2005) and it does not occur anymore, unless specific permit (e.g., scientific purposes). Dolphin-specific tourism related legislation is primarily focused on the prevention of boat disturbances. In Fernando de Noronha archipelago, Ibama (national environmental agency) concedes special permits for scientists and film crew to dive-with-spinner dolphins, Stenella longirostris (Gray, 1828), but tourist dive tours are not allowed.

There are no specific laws prohibiting wildlife provisioning inside conservation units in Brazil. However, it is prohibited by the internal regulations of some national parks (e.g., Serra dos Órgãos National Park; Ibama 2010). In these cases, those who ignore these regulations may be subject to fines. Presidential decree number 6514 (Brasil 2008b) article 30 states that the intentional disturbance of any species of cetacean, pinniped or sirenian in Brazilian waters is forbidden and lawbreakers subjected to fines. Article 90 of the same decree states that conducting any kind of activity or conduct counter to the objectives of the conservation unit, its management plan and regulations is also forbidden and is subject to fines as well. In addition, article 91 states that causing direct or indirect damage to conservation units is also forbidden and subject to fines. Feeding wildlife could be interpreted as an infringement of these articles in the decree, and also swimming with and touching animals such as dolphins could be similarly interpreted as infringements. Furthermore, these activities, if deliberate and proved harmful, could be considered as animal abuse. In this case, there are a variety of other specific laws which would prohibit such actions.

Despite existing since 1998, there are no laws regulating feeding, touching and swimming with botos in Brazil. It is urgent that a specific legislation be created, and also to define ways to ensure proper monitoring and surveillance of these activities, since it is clear that the tourism activity here described do not comply with the Brazilian legislation. This new industry based on close interactions with the botos is an opportunity to achieve benefits, but until now it has been wasted due to an improper management, and should be banned if not greatly improved.

\section{Managing and Monitoring the 'Botos Feeding TourisM'}

There are some efforts at all the four sites to reduce risks; however. there is an urgent need to improve the situation. In Novo Airão researchers and research activity are supported, but there is an immense and urgent need to better understand this activity and its impacts. Lessons from other locations, such as Tangalooma and Monkey Mia, where dolphins are provisioned, have shown that risks can be reduced with careful management and monitoring.

The regime utilized by the cruise ship when visiting Novo Airão could be used as a starting point and all other interactions could be controlled in a similar fashion. Further urgent measures such as keeping the floating structure away from the inner bay (in the case of Novo Airão), restricting and measuring fish amounts and banning touching the dolphins should be implemented. Swimming with the botos must be banned or conducted under strict rules and monitoring, and in this case life-jackets must be always used and each person must be allowed to stay in the water for only a brief stipulated period, among other rules. No alcohol must be on sale and its consumption must be forbidden at the four sites. The carrying capacity (the maximum numbers of tourists per day and in a time, especially the maximum number of tourists in the water, and maximum number of hours of activity per day- schedule) of all the four locations must be determined and respected; overcrowd causes additional disturbances to the animals and to the environment, decreases in the degree of satisfaction of the tourists and increases all kinds of risks; besides that, more people generally means more feeding. Feeding should be conducted only by trained personnel or under strict surveillance, in order to avoid injuries. Interactions 
occurring away from the floating structure must be banned.

Better infra-structure must be created, like a protected border for the animals that hit it do not harm themselves and do not harm the tourists, or a submersed platform, in the case of Novo Airão, which is even better in order to avoid accidents. Boat traffic in surroundings, especially in the Novo Airão case, must be strictly controlled (e.g., number of boats and maximum speed). A safety area surrounding the sites must be implemented by using signaling buoys, to protect both botos and swimmers. A voluntary individual code of conduct must be created and explained for all the participants to follow, correctly explaining how to behave and the risks involved in such activities, being complemented by careful supervision of all interactions, conducted by specialized staff. Interpretation educational activities (e.g., watch a lecture before participating in the interactions) must be conducted before all interactions, to assure a high level of learning and the increase of environmental awareness of the tourists participating. A wider public education program needs to be conducted in order to promote a greater understanding of the species and their general environment and the need to restrict provisioning and interaction to carefully managed venues. This education program should initially focus on local schools and fisher associations and then be extended to the wider society.

As described by Orams (1997), whales and dolphins in the wild are 'big business'. Hoyt (2001) reported that cetacean-focused tourism is a one billion US dollars industry attracting more than nine million people per year in 87 countries and territories. The line between commercial exploitation of aquatic wildlife and mutually beneficial interaction is particularly thin. The way the interaction is controlled and managed will make the difference (Orams 1994).

It is important to note that while this kind of tourism has significant risks, potential benefits also exist. Humans enjoy interacting with dolphins and whales and can obtain psychological benefits from it. There is evidence from other locations (Orams 1996) that these kinds of interactions, when carefully managed and combined with effective education, can prompt people to become more environmentally responsible. This new boto-based tourism in the Amazon region is poised at an important threshold. If managed carefully, it could bring benefits to the local region and reduce risks to an appropriate minimal level. If not, a tragedy is imminent.

\section{ACKNOWLedGements}

The authors would like to thank Duke University/Oak Foundation for sponsoring this research, Cetacean Society International and Instituto Aqualie. David Janiger helped with references. The authors would also like to thank Marilda Medeiros, Gal, Monik, Marisa, Evellyn, Carol and Marcos (Novo Airão site), Curió (Ariaú site), William (Tarumã-Mirim site), Rosana and her family (Acajatuba site), Robson Henrique Carvalho, Rafael Pereira Pinto and ICMBio staff in Novo Airão, Eduardo Lage Bisaggio (Ibama agent), Fernanda Romagnoli, Vera M. Ferreira da Silva, Igor Simões, Camilah A. Zappes, Franciele Castro and the anonymous reviewers.

\section{REFERENCES}

Altmann, J. 1974. Observational study of behavior: sampling methods. Behaviour 49: 227-267.

Alves, L.C.P.S.; Andriolo A.; Orams M.B. \& Azevedo A.F. 2009. Close interactions with the Amazon boto (Inia geoffrensis) in the State of Amazonas, Brazil. In: IV Simpósio Internacional de Meio Ambiente, Rio de Janeiro, p. 374-377.

Brasil. 2000. Lei 9985, de 18 de Julho de 2000. Available at http://www.planalto.gov.br/ccivil/leis/L9985.htm; retrieved on 19 Mar. 2010.

Brasil. 2008a. Lei 11771/08. Available at http:// www.leidireto.com.br/lei-11771.html; retrieved on $20 \mathrm{Mar}$ 2010.

Brasil. 2008b. Decreto 6514. Available at http:// www.leidireto.com.br/decreto-6514.html; retrieved on 20 Mar. 2010.

Connor, R.C. \& Smolker, R.S. 1985. Habituated dolphins (Tursiops sp.) in Western Australia. Journal of Mammalogy 66(2): 398-400.

Gravena, W. 2007. Isolamento e Caracterização de Marcadores Microssatélites para Análises de Parentesco no Botovermelho (Inia geoffrensis). MSc dissertation. Instituto Nacional de Pesquisas da Amazônia and Universidade Federal

Sitientibus série Ciências Biológicas 11(1): 8-15. 2011. da Amazônia.

Hoyt, E. 2001. Whalewatching 2001 - Worldwide tourism, numbers, expenditures and expanding socioeconomic benefits. International Fund for Animal Welfare, Crowborough. Available at http://www.oceania.org.au/soundnet/features/ hoytifaw.html; retrieved on 20 Mar. 2010.

Ibama (Instituto Brasileiro do Meio Ambiente e dos Recursos Naturais Renováveis). 2010. Regras de Uso Público no Parque Nacional da Serra dos Órgãos. Available at http:// www.icmbio.gov.br/parnaso/index.php?id_menu=92; retrieved on 20 Mar. 2010.

Lockyer, C. 1990. Review of incidents involving wild, sociable dolphins worldwide. In: S Leatherwood \& R.R. Reeves (eds), The Bottlenose Dolphin. Academic Press, San Diego, p. 337353

Marino, L. \& Lilienfeld, S.O. 2007. Dolphin-assisted therapy: more flawed data and more flawed conclusions. Anthrozoös 20(3): 239-249.

Martin, A.R. \& da Silva, V.M.F. 2006. Sexual dimorphism and body scarring in the boto (Amazon river dolphin) Inia geoffrensis. Marine Mammal Science 22(1): 25-33.

Orams, M.B. 1994. Tourism and marine wildlife: the wild dolphins 
of Tangalooma, Australia. Anthrozoös 7(3): 195-201.

Orams, M.B. 1996. Managing Interaction between Wild Dolphins and Tourists at a Dolphin Feeding Program. Tangalooma, Australia. PhD Thesis. The University of Queensland.

Orams, M.B. 1997. Historical accounts of human-dolphin interaction and recent developments in wild dolphin based tourism in Australasia. Tourism Management 18(5): 317326.

Orams, M.B. 2002. Feeding wildlife as a tourism attraction: Issues and impacts. Tourism Management 23(3): 281-293.

Orams, M.B.; Hill, G.J.E. \& Baglioni, A.J. 1996. "Pushy" behaviour in a wild dolphin feeding program at Tangalooma, Australia. Marine Mammal Science 12(1): 107-117.

Romagnoli, F.C. 2009. Interpretação Ambiental e Envolvimento Comunitário: ecoturismo como ferramenta para a conservação do boto-vermelho, Inia geoffrensis. MSc dissertation. Instituto Nacional de Pesquisas da Amazônia.

Rose, N.A.; Weinrich, M. \& Finkle, M. 2005 Swim-with-whales tourism-an updated review of commercial operations. Jornal of Cetacean Research and Management, SC/57/WW/6: 1-15. Available at http.//www.cethus.org/pdf/swim-withwhales_tourism_an_update_review_of_commercial_operations_sc_57_ww6.pdf.

Santos, M.C.O. 1997. Lone sociable bottlenose dolphin in Brazil: human fatality and management. Marine Mammal Science 13(2): 355-356.

Shane, S.H.; Wells, R.S. \& Wursig B. 1986. Ecology, behavior and social organization of the bottlenose dolphin: a review. Marine Mammal Science 2(1): 34-63.

Whale and Dolphin Conservation Society. 2006. Dolphin Therapy in the Headlines. Available at http://www.wdes.org.au retrieved; retrieved on 27 Mar. 2010. 